\title{
Volatility Spillover Effects Between Stock Prices and Exchange Rates in Emerging Economies: Evidence from Turkey
}

\author{
Erick Lusekelo Mwambuli (Corresponding author) \\ School of Accounting, Dongbei University of Finance and Economics (DUFE), P.R \\ China \\ Faculty of Accounting, Banking and Finance, Institute of Finance Management (IFM), \\ Tanzania \\ E-mail: erickmwambuli@gmail.com
}

Professor Dr. Zhang Xianzhi

School of Accounting, Dongbei University of Finance and Economics (DUFE), P.R China

Zakayo S. Kisava

Department of Economics, Dokuz Eylul University, Turkey

Received: August 25, 2016 Accepted: October 25, 2016

doi:10.5296/ber.v6i2.10245

URL: http://dx.doi.org/10.5296/ber.v6i2.10245

\begin{abstract}
Volatility spillover effects between stock prices and exchange rates in emerging countries are a critical focus in the financial economics research arena. This paper focused to investigate the volatility spillover effects between stock prices and exchange rates of Istanbul stock exchange (ISE) by employing an exponential generalized autoregressive condition heteroskedasticity $(\mathrm{EGARCH})$ model. The period of study covered 11 years (i.e. 2005 to 2015) inclusive a period of the global financial crises (i.e. from 2005 to 2009) which resulted out from subprime mortgage in United States of America (USA).Our results suggest an existence of short run relationship between stock prices and exchange rates in Istanbul stock exchange (ISE).This empirical evidence suggest that there is symmetric volatility spillover between stock prices and exchange rates of Istanbul stock exchange (ISE) for full sample
\end{abstract}


employed as a result good and bad news has got a balanced effect to the market. The findings of the significant volatility spillover effects between exchange rates and stock prices suggest that, the markets are informationally efficient and one market exchange rate has significant predictive power of equal weight to another in case of two markets. Our study recommends investors and multinational firm managers to consider the general behaviour of the financial market before making decision whether to invest in or not since there is existence of relationship and volatility spillover between stock prices and exchange rates meanwhile economic policy makers both in Turkey and outside Turkey should consider these findings in their policy as one of the determinant to economic growth, as macroeconomic variable should be stable like exchange rates. Furthermore, this study may be extended after including of other variables which were not considered in this study like interest rate, inflation and agency theory.

Keywords: Volatility spillover, Stock prices, Exchange rate, EGARCH, Emerging economies, Istanbul Stock Exchange (ISE)

\section{Introduction}

Volatility is typically defined as a measure of dispersion of returns of an asset or market index. Generally, the higher the volatility, the riskier the asset. The fluctuation of factor over a period of time may be an indication of the volatility existence and the deviation of an expected return of the estimated value, is often described as Volatility. Financial volatility is a measure of deviation of price of a financial instrument or security over period, financial volatility is much of concern as it is one indication of the level of risk in the market or portfolio over a period of time (Giannellis et al., 2010). Volatility spillover also known as contagion, usually results from the normal interdependence among market economies. This interdependence means that shocks, whether of global or local nature, can be transmitted across countries because of their financial linkages. That volatility spillover can also be defined as the spread of the financial market disturbances from one point of the financial market in one country to another country or locally from one related variable to another variable, a process observed through co-movements in stock prices and exchange rates

Critically, an alteration in volatility in one country's financial market might be affected by the financial market volatility of other countries, a matter which is referred to as volatility spillover effects (Kalemli-Ozcan et al., (2010); Ke et al., (2010). In addition, according to Schwert (1983) volatility spillover effects of financial volatilities between country's stock prices and exchange rates has been changing, which has important impacts for policymakers and investors. Investment decisions might be affected by financial volatility spillover effects, as investors may equate higher volatility with greater risk.

\subsection{Background and Significance of the Study}

The main focus of this study is to determine the volatility spillover effects between stock prices and exchange rates in Turkey's stock market context, the study itself is analytically important because many of the finance and economics literatures over the last three decades there has been an integration between financial markets while various researcher paying 
attention on the volatility spillover between two financial markets from different regions or countries, from developed countries, emerging markets and developing countries and ignoring the volatility spillover of financial markets in a single country. The developed countries have been extensively studied by most of researchers (see for example: Antonakakis (2012); Apergis and Rezitis (2001); Beer and Hebein (2011); Ebrahim (2000); Grobys (2015); Kanas (2000); Yang and Doong (2004). Countries with emerging markets (See Kumar, M (2013) for India, Brazil and South Africa, Kalemli-Ozcan et al (2010) and Ke et al (2010) for Saudi Arabia, Japan and Germany, Bala (2003) for Hong Kong and Japan. There are also some studies for emerging countries for instance (see, for examples; Adjasi et al. (2008); Fedorova and Saleem (2010); Li and Majerowska (2008); Oberholzer and Boetticher (2015); Okpara and Odionye (2012); Walid et al. 2011).

This study focused to make investigation about volatility spillover between stock prices and exchange rates in a single country by using EGARCH model, Turkey as evidence to the study. The significance behind Istanbul stock exchange (Turkey) selection is due to the fact that the prior literatures don't provide enough evidence in the specific area of study. This study considered the latest sample as from 2005 to 2015 which will be of the best contribution in the following aspects. Firstly, instead of examining and analyzing several markets, our study investigates volatility spillover between stock prices and exchange rates for single market in time which will give new history in the financial and financial economics field as reference. Secondly, our study also will offer some new valuable knowledge and ideas to some of the related existing literatures in terms of the choice of country for the stock market selection sample. Thirdly, our study used daily dataset because stock prices and exchange rates are traded on the daily basis in the market and the shocks that arise on the daily bases are captured easily and will be used by investors and decision makers as well as policy makers on making forecasting of the economy of the country.

Financial volatility spillover effects have also been of interest study to many scholars especially to economic policymakers, as these volatility spillover effects may negatively affect economic performance and financial sectors performance of the country. (Becketti and Sellon, 1989). Policymakers are much concerned with viability of financial institutions and the smooth functioning of financial markets which may be threatened by increasing financial volatility spillover effects. Therefore, a proper understanding of the origins and drivers of volatility across markets is important for the decisions of policy makers, investors and other stakeholders at large.

The rest of the paper is organized as follows. The second section presents the literature, third section presents the research methodology, fourth section shows the results and discussion, and the lastly section, fifth section presents the conclusions, recommendations and policy implication.

\section{The Relevant Literature Review}

In the Past Three Decades the relationship between stock prices and exchange rates has received considerable attention in the literature, these literatures has been classified into two groups as theoretical and empirical aspects 


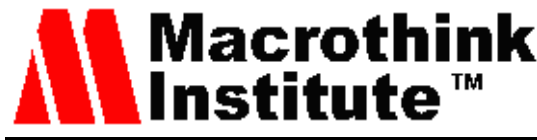

Business and Economic Research

ISSN 2162-4860

2016, Vol. 6, No. 2

Economic theories such as the Balance of Payment Approach (Dornbusch and Fischer, 1980) and the Portfolio Approach (Branson, 1983) suggest that there is interdependence between the volatility of stock and foreign exchange markets. Moore and Wang (2014) argue that the sign size and direction of this interdependence depends upon the financial integration and market efficiency of the country and whether the economy is export or import dominant. Most of the existing research on the inter-temporal dependence of the volatility of asset markets tends to focus on developed countries (Yang \& Doong, 2004; Raghavan \& Dark, 2008) or on individual developing countries (Mishra et al, 2007) with less attention being paid to the relationship in question from the perspective of both emerging and developed countries. This is striking when considering that country specific variables such as the degree of capital mobility, trade volumes and the inter relationship between macroeconomic variables may also impact the volatility spillover effects between foreign exchange and stock markets in a country.

Several theoretical model has used to determine the relationship between stock prices and exchange rates by paying attention on the literature example (Aggarwal, 1981; Bahmani-Oskooee \& Sohrabian, 1992; Ajayi \& Mougoue, 1996; Ajayi et al, 1998; Granger et al., 2000; Apte, 2001; Nieh \& Lee, 2001; Phylaktis \& Ravazzolo, 2005; Antell \& Vaihekoski, 2007; Lin-yueqin, 2012; Moore \& Wang, 2014). A number of these literatures which concentrated on the "first moment" co-movement, the cointegration properties, and the direction of causality of the variables in question confirmed a significant relationship between stock prices and exchange rates.

Ma and Kao (1990) on their paper they examined the exchange rate on the stock prices in Iran. On their study they employed GARCH model. GARCH model has shown the positive relationship between exchange rate and stock prices. Wu (2005) examines the volatility spillover effects between stock prices and exchange rates of Indian markets, South Korea, Indonesia, Philippines, Singapore, Thailand and Taiwan for the period 1997-2000, splitting the data into pre-Asian financial crisis and post-crisis periods. The study reported a bi-directional spillover effect between the variables during the recovery period in almost all countries.

It is well known from the above review of relevant literature that the findings on volatility spillover effects between stock prices and exchange rates are rather mixed with no clear consensus from which to discern a conventional wisdom. The results vary from country to country also depending on the methodology adopted as well as the quantity, quality and period span of data employed. There is, therefore, value in investigating further the effects of volatility spillovers between exchange rates and stock prices particularly by comparing the experience of a sample of both developed and emerging markets within the same framework across pre-crisis crisis and post-crisis periods using the same methodology and time span and an up-to-date dataset.

Qayyum and Kemal (2006) made analysis on the volatility spillover between the stock market and the foreign exchange market in Pakistan for long term relationship, Engle and Granger two was employed, then volatility spillover was analyzed by using bivariate 
EGARCH method, their results estimated from cointegration suggested that, there is no long run relationship between two markets. Mishran et al., (2007) conducted a study on volatility spillover between the Indian stock and foreign exchange markets, on their study the dataset from $10^{\text {th }}$ October 1994 to $30^{\text {th }}$ December 2005 was employed and their results shown that, there is a bi-directional volatility spillover between the Indian stock market and foreign exchange market except for cases of S\&P, CNX, NIFTY and S\&P, CNX 500.

Kasman (2003) studied empirically the relationship between stock prices and exchange rates by using high frequency data of exchange rates and aggregate stock prices of Turkey, he used time series approach and his findings suggested that there is a long run stable relationship between stock prices and exchange rates. Özçam (2004) studied foreign exchange policies in Turkey, then he made volatility projection for the period between 1996 to 2003 same as to foreign exchange rates, interest rates and stock prices while studying volatility integration via models developed based on GARCH model process, his findings suggested that, the increase in foreign exchange prices adversely impacts the stock prices in the market, the volatility of rates was low and stable because central Bank was taking a closer control over it. Moreover with adoption of free market policy in foreign exchange rate by Central bank, the volatility of foreign exchange rates increased and began to stabilize a level lower than that of stock price volatility.

Badrinath, and Apte (2005) examined stock market, foreign exchange rates and call money market in India, they employed a multivariate EGARCH which facilitated the estimation of asymmetric responses in order to excel the evidence of volatility spillovers and their results shows that, there is an information asymmetric volatility spillover across two markets. Furthermore, Williams, and Liao (2007) used a multivariate GARCH model which allowed for interdependence between returns and time varying variance-covariance structure for the sake of examining conditional price discovery and volatility spillover processes in the BRICS countries and their findings suggest that, there are some element of predictability in asset prices though it was significantly lagged currency movements and the local stock market movements. Moreover it was found that, negative news to the market had a great impact on volatility and is necessary for asymmetric model.

Apte (2001) examines the volatility spillover effect between stock and foreign exchange markets in India as a country with emerging economy using a bivariate EGARCH model and daily data from 02 January 1991 to 24 April 2000. However, contrary to the findings of Kanas (2000), the study finds a significant volatility spillover from the foreign exchange market to the stock market and an insignificant volatility spillover from the stock market to the foreign exchange market. Mishra et al. (2007) point out that the major limitation of this study is that it generated the data on stock indices from 1991 to 1994 by simulation, he then employed EGARCH model and by extending the sample period, Mishra et al. (2007) find a bi-directional volatility spillover between stock and foreign exchange markets in India.

Walid et al. (2011) examine the impact of exchange rate changes on stock prices volatility in four emerging markets (Hong Kong, Singapore, Malaysia and Mexico). Using weekly data and employing a two regime Markov-Switching EGARCH model they find evidence of 
regime switching behaviour in volatility of emerging countries stock markets and the relationship between exchange rates and stock prices is regime dependent. Their evidence also indicates the volatility in foreign exchange markets spills over to stock markets asymmetrically.

\section{Research Methodology}

\subsection{Scope, Population and Sample}

This study aimed at analyzing the volatility spillover between stock prices and exchange rate in the countries with emerging economies by considering Turkey as the evidence. Turkey's stock market is named as Istanbul Stock Exchange (hereby referred as ISE), ISE is among the fastest growing market in the group of countries with emerging economy and it's the only stock market in Turkey. This study considered the period of 11 years of working days for stock market from 2005 to 2015.During this period, the global financial crises which resulted from subprime mortgage from 2000 to 2009 in USA and its effects spread all over the world is inclusive. Hence, makes our timeframe potential for this study to explore the volatility spillover between stock prices and exchange rates in a single stock market but trading with other stock market via exchanges rates.

The population for this study originate from 546 listed companies from ISE for the period of 11 years from 2005 to 2015. This study used the National 100 (ISE 100). ISE National 100 has been calculated since the inception. ISE is composed of national market companies except investment trusts. The constituents of the ISE National 100 Index are selected on the basis of pre-determined criteria directed for the companies to be included in the indices.

\subsection{Data Sources}

This study employed secondary data set which was extracted from Turkey Central BankEVDS as the main source database, The data used in this study consists of daily stock prices data which is calculated from the National market indexes (National 100 index) as the closing prices of the market and daily exchange rates (United States Dollar-USD against Turkish Lira-TL) covering the period from 2005 to 2015 . Daily returns by using of natural logarithm of the daily closing price relatives.

$$
r=\ln \left(\frac{P(t)}{P(-1)}\right)
$$

\subsection{Data Analysis}

Our study analyzed the financial data by using descriptive statistics and inferential statistics. Descriptive and inferential statistics variables were calculated using full sample from 2005 to 2015. Subsequently, the Cointegration test was analyzed to examine the existing relationship between variables employed in this study and EGARCH Model analysis to examine the statistical significance of parameters. This analysis was carried out by employing E-VIEWS 9 statistical package comprising 2764 observations. 


\subsection{Dependent and Independent Variables}

Our study employed different parameters to examine the volatility spillover between stock prices and exchange rates in the stock exchange evidenced to ISE. Stock Price (Price Index) denotes Dependent variable and Exchange rate denotes Independent variable. Main reasons for these variables to be used were as follows: (1) stock prices volatility has got both positive and negative impact to the country's economy, hence this will be helpful for economical decision making as well as for policy makers. (2) Exchange rates as dependent variable stipulates the existing relationship between one market and another with regardless to their location, this will help to understand the variable spillover from one market to another market both in positive and negative manner.

\subsection{EGARCH Method}

The empirical analysis for exploring volatility spillover is aimed to be captured by using Exponential Generalized Autoregressive Conditional Heteroscedasticity (EGARCH) model developed by (Nelson 1991). The simple GARCH model captures symmetric shocks i.e. positive shocks and is unable to capture asymmetric shock i.e. negative shocks. It is widely argued that negative shocks are likely to create more volatility than positive shocks having the same magnitude. The EGARCH model is able to capture both symmetric and asymmetric shocks.

EGARCH is capable of capturing the most important stylized features of stock return volatility, namely volatility clustering, negative correlation with return, logarithm normality and under certain specifications.

The model specification is as follows.

\section{Mean equations:}

$$
\begin{aligned}
& S_{t}=\theta_{s, 0}+\sum_{i=1}^{k} \theta_{s, i} S_{t-i}+\sum_{i=1}^{k} \theta_{e, i} E_{t-i}+\alpha_{s} \lambda_{s t-1}+\varepsilon_{s, t} \\
& E_{t}=\theta_{s, 0}+\sum_{i=1}^{k} \theta_{s, i} S_{t-i}+\sum_{i=1}^{k} \theta_{\theta_{i}, i} E_{t-i}+\alpha_{s} \lambda_{s t-1}+\varepsilon_{s, t}
\end{aligned}
$$

Conditional variance equations:

$$
\begin{aligned}
& \sigma_{s, i}^{2}=\exp \left\{\alpha_{s, 0}+\sum_{i=1}^{k} \beta_{s, i} \log \left(\sigma_{s, t-i}^{2}\right)+\sigma_{s, s}\left[\left(\left|Z_{s, t-1}\right|-E\left|Z_{s, t-1}\right|\right)+\pi_{s, s} Z_{s, t-1}\right]+\right.
\end{aligned}
$$

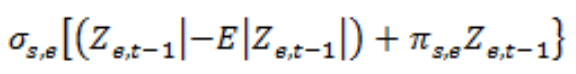

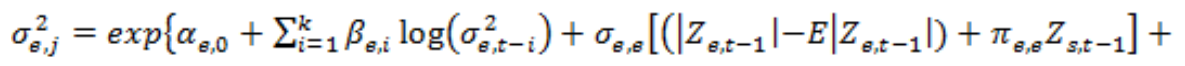

$$
\begin{aligned}
& \sigma_{\theta, s}\left[\left(Z_{s, t-1}|-E| Z_{s, t-1} \mid\right)+\pi_{\theta, s} Z_{s, t-1}\right\}
\end{aligned}
$$




$$
\begin{aligned}
& \sigma_{e, s, t}=\rho_{s, e, t} \sigma_{s, t} \sigma_{e, t} \\
& \sigma_{e, s, t}=\rho_{e, s, t} \sigma_{e, t} \sigma_{s, t}
\end{aligned}
$$

In equations (1) and (2) analyzes the volatility spillover effect between foreign exchange rate changes (E) and stock market returns (S). Here, $\boldsymbol{\alpha}$ denoted the coefficient of error correction terms, $(\lambda)$ and $\theta$ measures the (return) spillover effect. A lag length equal to two (2) is selected for both $\mathrm{E}$ and $\mathrm{S}$ on the basis of the AIC with lower value.

In equations (3) and (4) the conditional variance in one variable depends on its own lags and cross market standardized innovations. The existence of volatility is measured by $\beta$. The volatility spillover effect between foreign exchange rates and stock markets is captured by the

coefficient $\sigma$. If $\sigma_{s_{y} e}$ is statistically significantly different from zero, then there is the persistence of volatility on foreign exchange rates spillover to volatility of stock prices. The asymmetric impact is captured by the coefficient $\pi$. Asymmetry persists if $\pi$ is negative and statistically significantly different from zero. A positive and statistically significant $\sigma$ alongside a negative and significant $\pi$ amplify that negative shocks in one variable have a larger effect on the volatility of the other variable than positive shocks of the same absolute value. In other words, "bad news" has greater impact on volatility than "good news" in the market.

\section{Results and Discussion}

\subsection{Descriptive Statistics}

This part of study explains out the descriptive statistics of the selected sample covering a period from 2005 to 2015 for both stock prices and exchange rates in Turkey. The results for these descriptive information are stipulated in table 1 below: Mean values for stock price and exchange rates is $0.04 \%$ and $0.028 \%$ respectively, and these values narrates ISE has had a positive performance over the period of 2005 to 2015 though it was not the same for exchange rate and stock price. However, the Standard deviation for stock prices and exchange rates is $1.74 \%$ and $0.86 \%$ respectively, this suggest that the level of volatility spillover is low on the side of exchange rates transmitted from outside market. The value of kurtosis for stock prices and exchange rates is 6.45 and 21.99 respectively, which means that kurtosis return distribution is inconsistent or large magnitude returns occurs more frequently than a normal distribution in the ISE. Furthermore the Jarque-Bera for all variable concluded to be significant for the dataset selected. 


\section{Macrothink}

Business and Economic Research

ISSN 2162-4860

2016, Vol. 6, No. 2

Figure 1 and 2 represents the graphical representation of the stock index return data for the selected period from 2005 to 2015. The figures evidence that stock price and exchange rate are more volatile in the selected period though stock price seems to be more volatility over the same period selected as stock price is affected by other macroeconomics variables compared to exchange rate. This been verified in the study by the selected period even after 2007 stock volatility is higher compared to that of exchange rate. The volatility clustering in index (Price) and exchange rate is found more after the 2007 crises period.

Table 1. Descriptive statistics

\begin{tabular}{|l|c|c|}
\hline Variables & Stock Return & Exchange rate \\
\hline Mean & 0.0004 & 0.00028 \\
\hline Median & 0.0009 & -0.00022 \\
\hline Std. Dev. & 0.0174 & 0.00856 \\
\hline Skewness & -0.2635 & -0.16741 \\
\hline Kurtosis & 6.4536 & 21.99877 \\
\hline c & 1405.6190 & 41582.71000 \\
\hline Probability & 0.0000 & 0.00000 \\
\hline Observations & 2764.0000 & 2764.00000 \\
\hline
\end{tabular}

Source: E-VIEWS 9 Analysis of Data

Note: SD and J-B denote standard error and Jarque-Bera, respectively. Jarque-Bera is the test of null hypothesis that the residuals are normally distributed.

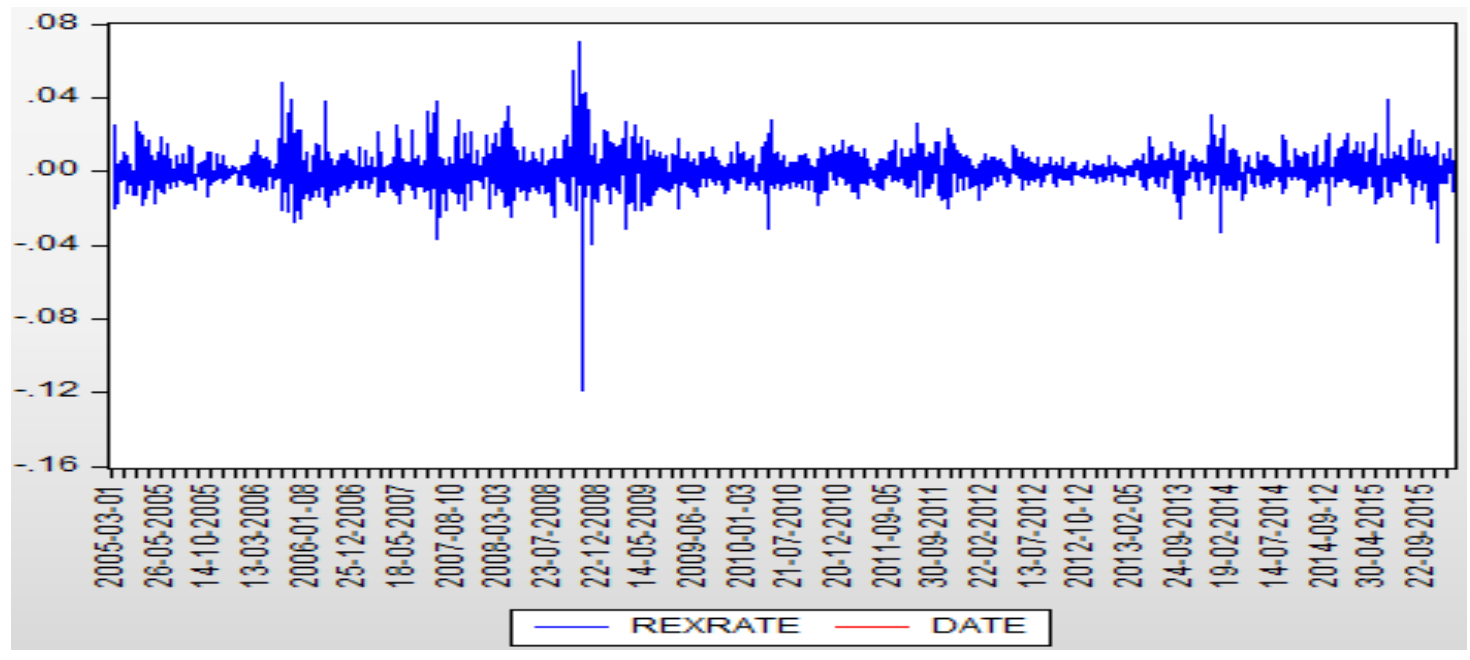

Figure 1. Exchange rate

Source: E-VIEWS 9 Analysis of Data 


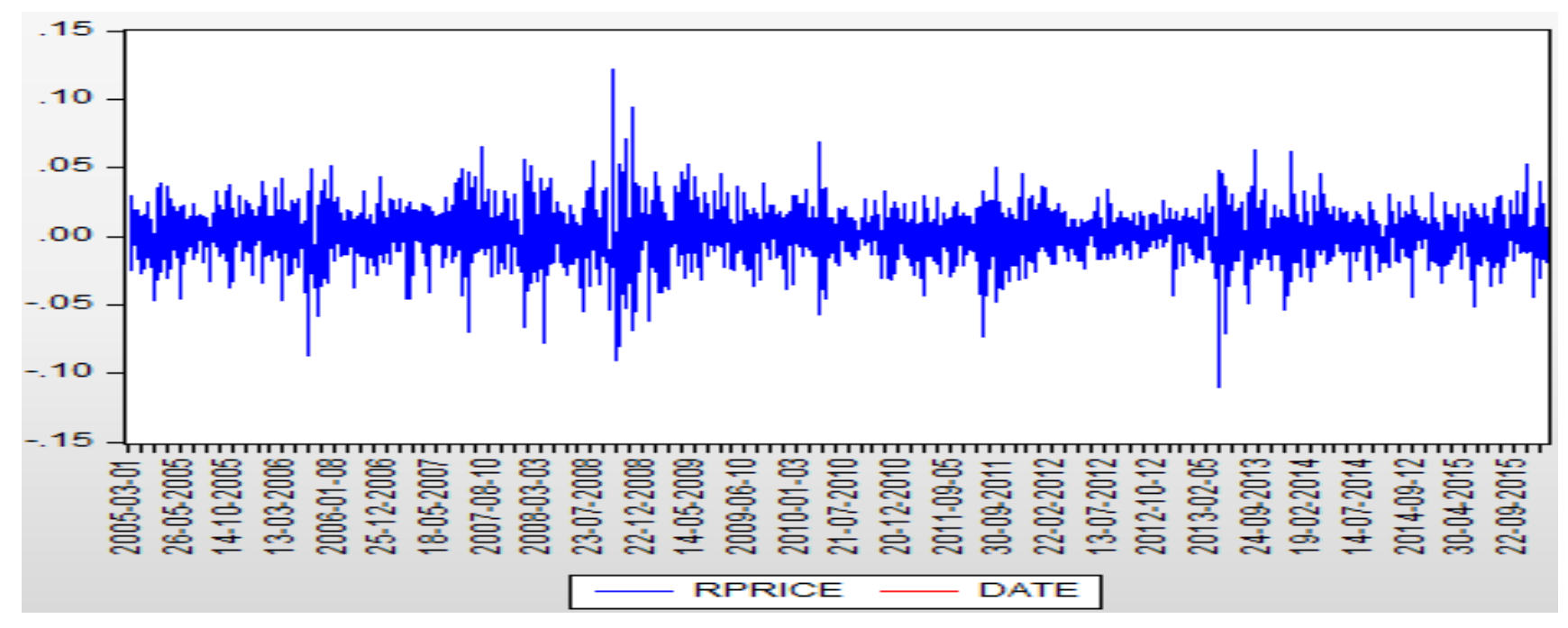

Figure 2. Return of stock price

Source: E-VIEWS 9 Analysis of Data

\subsection{EGARCH Estimations Preliminary Tests}

Prior to undertaking EGARCH estimations, our preliminary testing phase entailed assessing the stationarity, cointegration and autocorrelation test.

\subsubsection{Unit Root Test}

Table 2 shows the results of ADF, PP, and KPSS tests performed on the stock price and exchange rate returns of ISE. Results of ADF and PP tests suggest that the absolute value of t-statistics is lesser than the absolute critical value at 1,5 , and 10 percent significance levels for the index and exchange rate returns of the ISE. This indicates that all the time series are non-stationary (i.e. the null hypothesis has a unit root is accepted for all the series at level). Results of KPSS test are also in agreement with ADF and PP results, as the t-statistics is greater than the critical values at 1 and 5 percent significance level.

This findings force us to move forward further step and make another test in the first difference for all tests (i.e. ADF, PP and PKSS) and the result as shown in the table 2.However, after performing those tests on stock index and exchange rate for ISE, our test results suggest that the absolute value of t-statistics is greater ( $>$ ) than the absolute of critical value at 1 , and 5 percent significance level. This suggests that our data series are stationary at first difference level as for ADF and PP tests results. 
Table 2. Unit root tests

\begin{tabular}{|c|c|c|c|}
\hline & \multicolumn{2}{|l|}{ ADF } & \\
\hline Variable & $\mathrm{t}$-Statistics & Probability & Execution \\
\hline Stock Price & -1.6794 & 0.4417 & Not Stationary \\
\hline \multirow[t]{2}{*}{ Exchange } & 1.227526 & 0.9984 & Not Stationary \\
\hline & \multicolumn{2}{|l|}{$\mathbf{P P}$} & \\
\hline Stock Price & -1.6844 & 0.4392 & Not Stationary \\
\hline \multirow[t]{2}{*}{ Exchange } & 1.275453 & 0.9986 & Not Stationary \\
\hline & \multicolumn{2}{|l|}{ KPSS } & \\
\hline Stock Price & 5.46045 & 0.739 & Not Stationary \\
\hline \multirow[t]{3}{*}{ Exchange } & 5.16762 & 0.739 & Not Stationary \\
\hline & First Differenced & & \\
\hline & \multicolumn{2}{|l|}{ ADF } & \\
\hline Stock Price & -52.993 & 0.0001 & Stationary \\
\hline \multirow[t]{2}{*}{ Exchange } & -52.1991 & 0.0001 & Stationary \\
\hline & \multicolumn{2}{|l|}{$\mathbf{P P}$} & \\
\hline Stock Price & -52.992 & 0.0001 & Stationary \\
\hline \multirow[t]{2}{*}{ Exchange } & -52.198 & 0.0001 & Stationary \\
\hline & \multicolumn{2}{|l|}{ KPSS } & \\
\hline Stock Price & 0.05412 & 0.739 & Stationary \\
\hline Exchange & 0.421319 & 0.739 & Stationary \\
\hline
\end{tabular}

Source: E-VIEWS 9 Analysis of Data

\subsubsection{Cointegration Test}

The results of the Johansen cointegration tests are reported on table 3 for the full sample period. The result indicates conitegrating relationships between stock prices and exchange rates only in the short run but not in the long run period for ISE. None means no cointegration between the variables in long run, Ho: if $\mathrm{P}<5 \%$ reject null hypothesis means no cointegration, while $\mathrm{H} 1$ : there is cointegration $\mathrm{P}>5 \%$.

Result are as follows, Prob. ${ }^{* *} 0.4898$ and 0.2337 for none and at most 1 under trace statistics respectively. Maximum eigenvalue for none* Max eigenvalue greater than critical value then reject the null hypothesis, at most 1 max eigenvalue less than critical value then accept alternative hypothesis. However, our results justify the exclusion of the error correction terms in full sample period. So these results suggest that there is short run relationship between stock index and exchange rate of ISE for full sample. Furthermore, our findings of Johansen cointegration tests are consistent with the findings of earlier studies for emerging countries under Ocran (2010), Tabak (2006) and Kumar (2013). Moreover this result goes inversely with the findings of $\mathrm{Wu}(2005)$ and Apte (2001) on emerging markets, Turkey inclusively. 
Table 3. Cointegration tests

\begin{tabular}{|c|c|c|c|c|}
\hline Hypothesized & & Trace & $5 \%$ & \\
\hline No. of CE(s) & Eigenvalue & Statistic & Critical Value & Prob.** \\
\hline & & & & \\
\hline None & 0.002301 & 7.775191 & 15.49471 & 0.4898 \\
\hline At most 1 & 0.000514 & 1.418007 & 3.841466 & 0.2337 \\
\hline & & & & \\
\hline Hypothesized & & Max-Eigen & $5 \%$ & \\
\hline No. of CE(s) & Eigenvalue & Statistic & Critical Value & Prob.** \\
\hline & & & & \\
\hline None & 0.002301 & 6.357184 & 14.2646 & 0.5678 \\
\hline At most 1 & 0.000514 & 1.418007 & 3.841466 & 0.2337 \\
\hline
\end{tabular}

Source: E-VIEWS 9 Analysis of Data

Note: Hypothesis is for this test is the number of Cointegration Equations (CE) are less than or equal to the number specified. Trace and Max-Eigen are the standard Johansen test statistics for testing for cointegration.

\subsubsection{Serial Correlation Test}

The presence of serial correlation in the data series will result into inaccuracy of results for the statistical and econometrical models, to ensure whether our dataset suffers from serial correlation for the period employed in this study (i.e. from 2005 to 2015) we then employed Breusch-Godfrey serial correlation LM . H0: there is no serial correlation, means probability values are greater than $5 \%$ and $\mathrm{H} 1$ : there is serial correlation, means probability values are lesser than $5 \%$.Our findings in table 4 suggest our data series for stock index and exchange rate are free from serial correlation, hence we accept null hypothesis and reject alternative hypothesis.

Table 4. Autocorrelation test

\begin{tabular}{|l|c|}
\hline F-statistic & 1.333265 \\
\hline Prob. F(2,2760) & 0.2638 \\
\hline Obs*R-squared & 2.667817 \\
\hline Prob.Chi-Square (2) & 0.2634 \\
\hline
\end{tabular}

Source: E-VIEWS 9 Analysis of Data

\subsection{EGARCH Estimation Results}

Table 5, presents the EGARCH estimations results for the full sample period. Volatility persistence of stock prices and exchange rates are measured by $\beta, \beta$ is statistically significant. There is volatility spillover effects from exchange rates to stock prices for full sample, our results indicates an effect transmission from exchange rates fluctuation to stock prices of the ISE, furthermore, the negative sign of the significant $\pi$ indicates that unexpected "bad news" has a greater effect on the volatility than unexpected "good news". Moreover, the insignificant $\pi$ for the stock price and exchange rate suggests that volatility spillover effects are symmetric, which means that good and bad news have an equal impact on volatility for 
stock price and exchange rate. Our study has not produced evidence in support of a volatility spillover in the opposite direction.

Our findings are consistent with those of Walid et al. (2011) and Apte (2001), a unidirectional (opposite) volatility spillover from exchange rates to stock prices in emerging economies Turkey inclusive.

Furthermore, these findings are supporting those by Mishra et al. (2007) and Wu (2005), who found a bi-directional volatility spillover between stock prices and exchange rates in emerging countries contrary to the findings of Raghavan and Dark (2008).

Table 5. EGARCH estimation results

\begin{tabular}{|l|c|c|c|c|}
\hline $\mathrm{c}$ & Parameters & Coefficients & Probability & \\
\hline Parameters & Price & exchange & Prob* & Price \& exchange \\
\hline$\delta$ & 0.168854 & 0.231948 & 0.0000 & 0.16910 \\
\hline$\pi$ & -0.089971 & 0.076097 & 0.0000 & -0.08873 \\
\hline$\beta$ & 0.952927 & 0.971644 & 0.0000 & 0.46819 \\
\hline
\end{tabular}

Source: E-VIEWS 9 Analysis of Data

Note: Stock and Ex (exchange rates) denote the conditional variance equations (3) and (4), respectively. The persistence of volatility, volatility spillover from one variable to another, and the asymmetric spillover effect are measured by $\beta, \delta$ and $\pi$ respectively.

\section{Conclusion and Recommendations}

\subsection{Conclusion}

Our study examined the volatility spillover between stock prices and exchange rates for the ISE, Turkey as among the emerging market in the world for the period covering from January 03, 2005 to December 25, 2015 in order to explore the spillover between stock price and exchange rates as two important factors or variables of an economy. Before we employed the GARCH estimation model, we considered the following preliminary tests. Firstly we employed unit root tests to find the stationarity of stock prices and exchange rates for the ISE and the results show that all the data series are stationary. Secondly, we employed Johansen cointegration methodology to test for the cointegrating relationship between the selected variable in the market and the results shows that there is no cointegrating relationship between stock prices and exchange rates in the long run but only exist in the short run. Thirdly and lastly, we then employed Breusch-Godfrey serial correlation LM and results shows that our data are free from autocorrelation. Our GARCH estimation results report a volatility spillover effects from exchange rates to stock prices for full sample. Furthermore, the negative sign of the significant $\pi$ indicates that unexpected "bad news" has a greater effect on the volatility than unexpected "good news", however our study has not produced evidence in support of a volatility spillover in the opposite direction.

\subsection{Recommendations}




\subsubsection{Economic Policy and Decision Makers}

Findings of this study will be important for economic policy makers in order to safeguard the financial sector from international financial shocks which affects economy directly. The information concerning volatility spillover between stock prices and exchange rates in the country would be of greater interest for policy makers and decision makers for economic stability since financial markets integration through exchange rates imply financial sector integration. Moreover, policy makers may be able to implement successful policies by having information about behaviour of stock exchanges.

\subsubsection{Financial Investors}

Investor through these results would be able to predict any future crises in the stock market, if and only if they have some historical information about financial market (exchange rates) integrations and volatility spillover. Furthermore, investors who want to make efficient portfolios can use these findings to reduce their risk and increase their returns, and make decisions in the selected markets. The market participants may consider the relationship between the exchange rate and stock prices to predict the future movement of each factor.

\subsubsection{Future Research}

The future study may be extended after including of other variables which were not considered in this study like interest rate, inflation and agency theory.

\section{References}

Adjasi, C., Harvey, S. K., \& Agyapong, D. A., (2008). Effect of exchange rate volatility on the Ghana stock exchange, African Journal of Accounting, Economics, Finance and Banking Research, 3(3).

Aggarwal, R. (1981). Exchange rates and stock prices: A study of US capital market under floating exchange rates, Akron Business and Economic Review. 12, 7-12.

Ajayi, R. A., Friedman, J., \& Mehdian, S. M. (1998). On the relationship between stock returns and exchange rates: Tests of Granger causality. Global Finance Journal, 9(2), 241-51. http://dx.doi.org/10.1016/S1044-0283(98)90006-0

Ajayi, R. A., \& Mougoue, M. (1996). On the dynamic relation between stock prices and exchange rates. Journal of Financial Research, 19, 193-207. http://dx.doi.org/10.1111/j.1475-6803.1996.tb00593.x

Antell, J., \& Vaihekoski, M. (2007). International asset pricing models and currency risk: Evidence from Finland 1970-2004. Journal of Banking and Finance, 31, 2571-2590. http://dx.doi.org/10.1016/j.jbankfin.2006.09.013

Antonakakis, N. (2012). Exchange return co-movements and volatility spillovers before and after the introduction of euro. Journal of International Financial Markets, Institutions \& Money, 22, 1091-1109. http://dx.doi.org/10.1016/j.intfin.2012.05.009

Apergis, N., \& Rezitis, A. (2001). Asymmetric cross market volatility spillovers: Evidence 
from daily data on equity and foreign exchange markets. The Manchester School, 69, 81-96. http://dx.doi.org/10.1111/1467-9957.69.s1.5

Apte, P. G. (2001). The interrelationship between stock markets and the foreign exchange markets, Prajnan, 1, 17-29. http://dx.doi.org/10.2139/ssrn.2161245

Badrinath, H. R., \& Apte, P. G. (2005). Volatility spillovers across stock, call money and foreign exchange markets. unpublished paper, 1-26.

Bahmani-Oskooee, M., \& Sohrabian, A. (1992). Stock prices and the effective exchange rate of the dollar. Applied Economics, 24, 459-464 http://dx.doi.org/10.1080/00036849200000020

Becketti, F., \& Sellon J. (1989). Robust non-parametric measures of exchange rate variability. Applied Economics, 24, 951-958.

Beer, F., \& Hebein, F. (2011). An assessment of the stock market and exchange rate dynamics in industrialized and emerging markets. International Business and Economics Research Journal (IBER), 7. http://dx.doi.org/10.19030/iber.v7i8.3283

Branson, W. H. (1983). A model of exchange-rate determination with policy reaction: Evidence from monthly data. Cambridge- Mass (1050 Massachusetts Avenue, Cambridge 02138), National Bureau of Economic Research.

Breusch, T. S. (1978). Testing for autocorrelation in dynamic linier models. Australian Economic Papers, 17, 334-355. http://dx.doi.org/10.1111/j.1467-8454.1978.tb00635.x

Dickey, D., \& Fuller, W. (1979). Distribution of the estimators for auto-regressive time series with a unit root. Journal of American Statistical Association, 74, 427-431.

Dornbusch, R., \& Fischer, S. (1980). Exchange rates and the current account. American Economic Review, 70(5), 960-971.

Ebrahim, S. K. (2000). Volatility transmission between foreign exchange and money markets. working paper, Ottawa, Bank of Canada.

Fedorova, E., \& Saleem, K. (2010), Volatility spillovers between stock and currency markets: Evidence from emerging Eastern Europe. Czech Journal of Economics and Finance, 60, 519-533.

Giannellis, N., Kanas, A., \& Papadopoulos, A.P (2010). Asymmetric volatility spillovers between stock market and real activity: Evidence from the UK and the US. Panoeconomicus, 4, 429-445. http://dx.doi.org/10.2298/PAN1004429G

Granger, C. W. J., Huang, B. N., \& Yang, C. W (2000). A bivariate causality between stock prices and exchange rates: Evidence from recent Asian flu. Quarterly Review of Economics and Finance, 40(3), 337-354. http://dx.doi.org/10.1016/S1062-9769(00)00042-9

Grobys, K. (2015). Are volatility spillovers between currency and equity market driven by economic states? Evidence from the US economy. Economics Letters, 127, 72-75. http://dx.doi.org/10.1016/j.econlet.2014.12.034 
Kanas, A. (2000). Volatility spillovers between stock return and exchange rate changes: International evidence. Journal of Business Finance and Accounting, 27, 447-467. http://dx.doi.org/10.1111/1468-5957.00320

Kanas, A. (2002). Is exchange rate volatility influenced by stock return volatility? Evidence from the US, the UK and Japan. Applied Economics Letters, 9(8), 501-503. http://dx.doi.org/10.1080/13504850110095783

Kasman, S. (2003). The relationship between exchange rates and stock prices: A causality analysis. Dokuz Eylül Üniversitesi Sosyal Bilimler Dergis, 5, 70-79.

Kalemli-Ozcan, S., Sorensen, B. E., \& Volosovych, V. (2010). Deep financial integration and volatility. C.E.P.R. Discussion Papers: 7784

Ke, J., Wang, L., \& Murray L. (2010). An empirical analysis of the volatility spillover Effect between primary stock markets abroad and China. Journal of Chinese Economic and Business Studies, 8, 315-333. http://dx.doi.org/10.1080/14765284.2010.493645

Kumar, M. (2013). Returns and volatility spillover between stock prices and exchange rates: Empirical evidence from IBSA countries. International Journal of Emerging Market, 8(2), 108-128 http://dx.doi.org/10.1108/17468801311306984

Li, H., \& Majerowska, E. (2008). Testing stock market linkages for Poland and Hungary: A multivariate GARCH approach. Research in International Business and Finance, 22, 247-266. http://dx.doi.org/10.1016/j.ribaf.2007.06.001

Lin-Yueqin, L. (2012). China - emerging markets relations / review and analysis,ume 1, Reading, Paths International.

Ma, C. K., \& Kao, G.W. (1990). Exchange rate changes and stock price reactions”. Journal of Business Finance \& Accounting, 7(3), 441-449.

http://dx.doi.org/10.1111/j.1468-5957.1990.tb01196.x

Moore, T., \& Wang, P. (2014). Dynamic linkage between real exchange rates and stock prices: Evidence from developed and emerging Asian markets. International Review of Economics and Finance, 29, 1-11. http://dx.doi.org/10.1016/j.iref.2013.02.004

Nelson, D. B. (1991). Conditional heteroskedasticity in asset returns: A new approach. Econometrica, 59(2), 347-370. http://dx.doi.org/10.2307/2938260

Nieh, C. C., \& Lee, C. F. (2001). Dynamic relationships between stock prices and exchange rates for G-7 countries. Quarterly Review of Economics and Finance, 41(4), 477-490. http://dx.doi.org/10.1016/S1062-9769(01)00085-0

Oberholzer, N., \& Boetticher, S. T. V. (2015). Volatility spill-over between the JSE/FTSE indices and the South African rand. Procedia Economics and Finance, 24, 501-510. http://dx.doi.org/10.1016/S2212-5671(15)00618-8

Ocran, M. K. (2010). Exchange rate pass-through to domestic prices: The case of South Africa. Prague Economic Papers, 4, 291-306. http://dx.doi.org/10.18267/j.pep.378 
Okpara, G. C., \& Odionye, J. C., (2012). Analysis of the relationship between exchange rate and stock prices: Evidence from Nigeria. International journal of current research, 4(3), 175-183.

Özçam, M. (2004). Sermaye piyasası kurulu araştırma raporu. döviz kuru politikaları ve Türkiye'de döviz kuru oynaklığının etkileşimleri.

Phylaktis, K., \& Ravazzolo, F. (2005). Stock market linkages in emerging markets: implications for international portfolio diversification. Journal of International Financial Markets, Institutions \& Money, 15, 91-106. http://dx.doi.org/10.1016/j.intfin.2004.03.001

Qayyum, A., \& Kemal, A. R. (2006). Volatility spillover between the stock market and the foreign exchange market in Pakistan" PIDE Working Papers, 7, 1-16.

Raghavan, M. V., \& Dark, J. (2008). Return and volatility spillover between the foreign exchange market and the Australian all ordinaries index. The IUP Journal of Applied Finance, 14(1), 41-48.

Schwert, G. W (1983). Symposium on size and stock returns, and other empirical regularities. Amsterdam, North-Holland Publ. Comp.

Tabak, B. M. (2006). The dynamic relationship between stock prices and exchange rates: Evidence from Brazil. International Journal of Theoretical and Applied Finance, 9(08), 1377-1396. http://dx.doi.org/10.1142/S0219024906003974

Walid, C., Chaker, A., Masood, O., \& Fry, J. (2011). Stock market volatility and exchange rates in emerging countries: A Markov-state switching approach. Emerging Market Review, 12(3), 272-292. http://dx.doi.org/10.1016/j.ememar.2011.04.003

Williams, J., \& Liao, A (2007). Intergration,price discovery and volatility transmission: Evidence from FX and stock markets in the BRICs.Unpublished paper, BBS at the university of Wales. 1-47.

$\mathrm{Wu}, \mathrm{R}$. (2005). International transmission effect of volatility between the financial markets during the Asian financial crises. Transmission Studies Review, 15, 19-35.

http://dx.doi.org/10.1007/s11300-005-0032-5

Yang, S., \& Doong, S. (2004). Price and volatility spillovers between stock prices and exchange rates: Empirical evidence from the G-7 Countries. International Journal of Business and Economics, 3, 139-153.

\section{Copyright Disclaimer}

Copyright for this article is retained by the author(s), with first publication rights granted to the journal.

This is an open-access article distributed under the terms and conditions of the Creative Commons Attribution license (http://creativecommons.org/licenses/by/3.0/). 